\title{
Comparative Thermal Analysis of Different Cool Roof Materials for Minimizing Building Energy Consumption
}

\author{
Y. Anand, ${ }^{1}$ A. Gupta, ${ }^{1}$ A. Maini, ${ }^{2}$ Avi Gupta, ${ }^{2}$ A. Sharma, ${ }^{2}$ A. Khajuria, ${ }^{2}$ S. Gupta, \\ S. Sharma, ${ }^{2}$ S. Anand, ${ }^{1}$ and S. K. Tyagi ${ }^{3}$ \\ ${ }^{1}$ School of Energy Management, Shri Mata Vaishno Devi University, Katra, Jammu and Kashmir 182320, India \\ ${ }^{2}$ School of Mechanical Engineering, Shri Mata Vaishno Devi University, Katra, Jammu and Kashmir 182320, India \\ ${ }^{3}$ Sardar Swaran Singh National Institute of Renewable Energy, Kapurthala, Punjab 144601, India \\ Correspondence should be addressed to S. Anand; anandsanjeev12@gmail.com
}

Received 16 August 2014; Revised 19 November 2014; Accepted 26 November 2014; Published 18 December 2014

Academic Editor: Sergio Nardini

Copyright (C) 2014 Y. Anand et al. This is an open access article distributed under the Creative Commons Attribution License, which permits unrestricted use, distribution, and reproduction in any medium, provided the original work is properly cited.

\begin{abstract}
The roof and walls in the urban areas contribute to major share in the absorption of solar radiations and also retard the outflow of the absorbed radiation from the building envelope, thereby increasing the global warming by inducing the heat island effect. The impact of using cool roof technologies on the thermal comfort of the office buildings has been estimated. Cool roofs reduce electricity consumption for maintaining the temperature of the air-conditioned buildings in the comfort level and also increase comfort in buildings merely not relying completely on cooling equipment. The cool roofs and cool pavements, however, can mitigate summer urban heat islands by improving indoor air quality and comfort. The thermal analysis of different materials has been carried out to analyze the impact of the rate of heat transfer on the building envelope and the results obtained indicate that different cool roof techniques are beneficial in maintaining the comfort level of the building which purely depends on the ambient temperature conditions.
\end{abstract}

\section{Introduction}

Due to rapid change in the living standard besides climate changes and economic development, the energy use in buildings is continuously ascending and would be manyfold in the near future. Promoting energy efficient technologies as well as energy conservation in buildings is therefore becoming one of the major concerns for the scientific community. The building sector is one of the major energy consumers and contributes to about $40 \%$ of global energy consumption $[1,2]$. The substantial portion of the global energy is used to maintain room temperature within the comfort range of $20-22^{\circ} \mathrm{C}$. In the low-temperature areas, the actual demand for the useful or convertible energy for space heating and cooling is comparatively low whereas in high-temperature areas the demand increases and this demand can be extracted from the high grade energy sources such as electricity driven from fossil fuels. The energy use in building sector for maintaining thermal comfort and other applications is expected to mount up over the coming decades, which hence will make the situation worse due to an intermittent and unreliable status access to electricity supply in India. Another factor is rapidly developing national economies, homes, and businesses which will continue to demand more energy to cater greater productivity and a more comfortable standard of living. Exploding construction significantly not only raises the content of greenhouse gas emissions as well as strain on the energy system, but also presents a significant opportunity to implement energy efficient technologies in new buildings. The building sector, therefore, improvises a good threshold in improving the quality of the energy supply and demand. It has also been estimated that using energy efficiency measures for new buildings could reduce energy consumption on an average between 20 and 50\% [3]. Roof is the part of a building which experiences the maximum amount of solar radiation and in summers the traditional roof-surface temperature may rise up to $65^{\circ} \mathrm{C}$ [4] which accounts for several disadvantages. 
Furthermore, warm roofs radiate out heat into the atmosphere which eventually turns atmospheric air warmer too and acts as a driving agent to a phenomenon known as urban heat island effect. The urban heat island is a metropolitan area which is significantly warmer than its surrounding rural areas due to human activities like removal of natural vegetation and its replacement by buildings and paved surfaces [5] and consequently the urban areas experience an air temperature several degrees higher than the surrounding areas. This temperature difference with respect to the surrounding areas can reach up to $10^{\circ} \mathrm{C}$ [6-9]. One of the best passive solutions to reduce cooling load of the building which is comparatively higher than all electrical loads (lighting, electrical equipment, lifts, domestic hot water, and others) is cool roof technology. A published report revealed that peak summer season has pushed up the power consumption to 2300 megawatts (MW) whereas the Power Development Department (PDD) of the region under discussion has presently been able to provide only $1500 \mathrm{MW}$ from all its sources and faced a shortfall of around $800 \mathrm{MW}$ of power [10]. Another study revealed that electricity consumption can be brought down by $25 \%$ with adoption of cool roofs [11]. This prominent cool roof technology adopted in buildings throughout the globe helps in energy saving as well as improving building environment [12]. Another study on cool roof technology revealed savings up to $295,000 \mathrm{kWh}$ per year, which is equivalent to saving 59 million euros annually in electricity costs and the emission of $1,36,000$ metric tons of $\mathrm{CO}_{2}$ [13]. In addition to the above studies, a simulation study on cool roofs in the United States revealed that there is a decrease in peak electricity demand between 5.2 and $6.2 \mathrm{GW}$, equivalent to about 12-14 power plants of $0.5 \mathrm{GW}$ capacity each [14]. A joint ventured study by the U.S. Department of Energy (DOE) and the Environmental Protection Agency (EPA) revealed that replacing a black EPDM roof with a white thermoplastic Sarnafil could save up to $\$ 71,000$ (present value) in abated energy costs [15]. Various authors have worked in the field of different cool roof buildings. An analysis of cooler infrared reflective nonwhite coatings tiles on roof revealed that such coatings can be applied in situ to clay or clay tile roofs to reduce the building heat gain and cooling power demand besides adding aesthetic value to the building [16]. The concept of cool coatings in residential buildings for various climatic conditions revealed that increasing the roof reflectance reduces the cooling load by $18-93 \%$ and peak cooling demand in air-conditioned building by $11-27 \%$ [17]. The effect of the solar roof reflectance on the building heat gain suggests that light colored roofs have $30 \%$ lesser heat gain when compared to dark colored roof [18]. Again, a study of cool colored acrylic paints containing infrared reflective pigments indicated that cool colored paints when exposed to infrared radiations can reduce the surface temperature by $10^{\circ} \mathrm{C}$ in comparison to conventional paints and also increase the thermal comfort of the building envelope [19]. A case study based on the monitoring of the building with and without the eco-friendly paints for air temperatures, relative humidity, and solar radiation gave interesting as well as potential energy saving results with the cool painted roofs [20]. The global cooling updates for the reflective roofs and pavements in USA, Europe, and Asia were carried out which helped in the framing of new policies and programs based on the technology adopted [21]. Again, an analytical methodology to quantify cooling energy saving on the commercial buildings indicates that white roofs can save energy ranging from 20 to $22 \mathrm{kWh} / \mathrm{m}^{2}$ of roof area which corresponds to cooling energy reduction of $14-26 \%$ ultimately leading to an annual reduced $\mathrm{CO}_{2}$ emission of $11-12 \mathrm{~kg} \mathrm{CO} / \mathrm{m}^{2}$ of flat roof area [22]. A comparative and innovative study based on nanomaterials with improved near infrared capabilities for building envelope to identify the main aging factor affecting the reflective properties of paints revealed that such materials coated with nanomaterials can reduce solar reflectance by $10 \%$ [23]. A review on the exergy analysis of renewable energy based systems for buildings revealed that exergy analysis has been widely applied in parallel with energy analysis to find out the rational use of energy [24].

On the basis of the literature reviewed about the application of various cool roofing techniques and various shortcomings in the past literature, the present study deals with the application of the three cool roof materials commercially available in the typical Indian markets. The thermal analysis of the different materials has been carried out to analyze the impact of heat transfer rate on building envelope which in turn can reduce the electricity consumption for maintaining the temperature of the building in the comfort level. The effect of the ambient temperature on the rate of heat transfer has also been studied in the analysis.

\section{Site Description}

The application of various cool roofing techniques has been carried out for the two office rooms located in the Central Workshop premises at Shri Mata Vaishno Devi University (SMVDU) campus near Katra town in Reasi district of the Indian state of Jammu and Kashmir situated in the foothills of the Trikuta Mountains, where the holy shrine of Mata Vaishno Devi is located. It is located $42 \mathrm{~km}$ from the city of Jammu and is having typical hot and humid climate. Katra is located at $32.98^{\circ} \mathrm{N}, 74.95^{\circ} \mathrm{E}$ [25] and has an average elevation of 754 meters $(2,474$ feet).

2.1. Pictorial View of the Site. The 3-dimensional and 2dimensional views of the two office rooms have been considered where cool roof technology has been applied. In 3dimensional views of the site three different angles, that is, front, top, and side, are taken so that proper orientation of the site could be depicted and are shown in Figures 1(a), 1(b), and 1(c), respectively. The 2-dimensional view of the site shows all the walls, windows, and doors with allotted numbers. The two office room sites contain nine walls, two doors, and 3 windows which can be seen in Figure 2. However, the construction details of two office rooms (site on which cool roof technology has been applied) are listed in Tables 1 and 2 .

\section{Methods and Materials}

The description of the proposed work involves the application of cool roof pavements for minimizing the heat gain through 


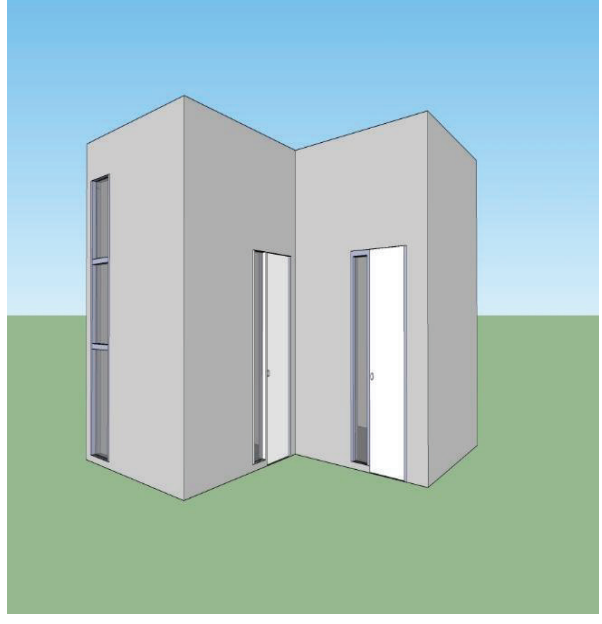

(a)

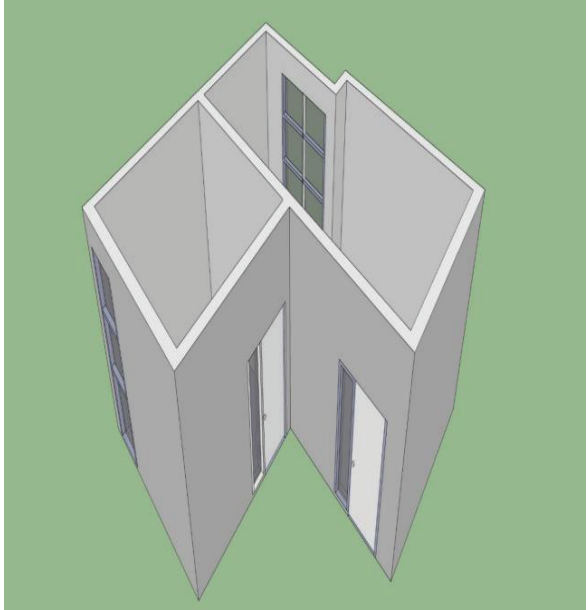

(b)

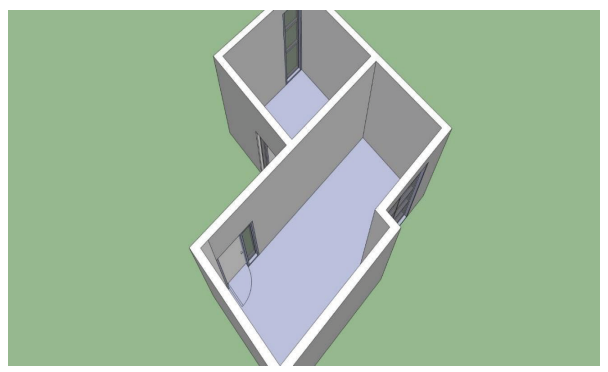

(c)

Figure 1: (a) Front 3D view of the site. (b) Side 3D view of the site. (c) Top 3D view of the site.

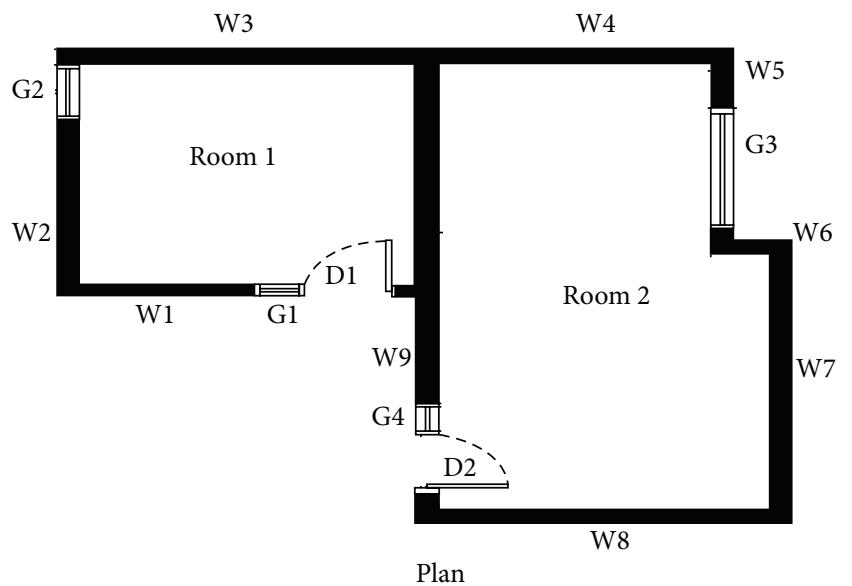

FIgURE 2: Two-dimensional plan of the site.

the roof of a selected building/location. The calculations are based on the total heat gain through the bare roofs as well as heat gain through the roofs after applying cool roof coatings. The cool roof pavements have been applied on the roof top of both office rooms and the materials selected as cool roof pavements are commercially available in typical Indian markets and the standard procedure for the application of these coatings is adopted as detailed in the manufacturers' manual. The technical specifications of the cool roof materials as per British Standard European Norm (BS EN) and American Standard for Testing and Materials (ASTM) are listed in Table 3.

The observations were recorded using Fluke 572-2 HighTemperature Infrared Thermometer as monitoring equipment whose feature and technical details are listed in Table 4. The Fluke 572-2 High-Temperature Infrared Thermometer is one of the best instruments that can be used in hightemperature industrial environments all around the world. This instrument finds its application for wider spectrum such as power utility, metal refining, smelting, glass, cement or petrochemical environments because the 572-2 model carries the most accurate, high-temperature, and high distance-tospot measurements. With a straightforward user interface and soft-key menus, the Fluke 572-2 makes even complex measurements easy. However, various sensors (K-type of thermocouples) external contact probes were also used to measure outdoor air temperature and roof surface temperature and the said specifications are listed in Table 5.

\section{Results and Discussions}

The roof is the biggest portion of the building which absorbs the maximum solar radiation and the heat gain from the building could be reduced by the application of the cool roof paints. The cool roof technology analysis is based on the 
TABLE 1: Physical and thermal properties of different constituents materials of room 1.

\begin{tabular}{|c|c|c|c|c|c|c|}
\hline \multicolumn{7}{|c|}{ Room 1} \\
\hline \multirow{2}{*}{ S. number } & \multirow{2}{*}{ Component of the room } & \multirow{2}{*}{ Quantity } & \multirow{2}{*}{ Material } & \multicolumn{3}{|c|}{ Physical and thermal properties } \\
\hline & & & & Thickness (m) & Surface area $\left(\mathrm{m}^{2}\right)$ & Thermal conductivity $(\mathrm{W} / \mathrm{m}-\mathrm{K})$ \\
\hline 1 & Door & 1 & Wood & 0.035 & 2.120 & 0.150 \\
\hline \multirow{3}{*}{2} & \multirow{3}{*}{ Wall } & \multirow{3}{*}{3} & Brick & 0.228 & Wall $1=8.029$ & 0.710 \\
\hline & & & \multirow{2}{*}{ Plaster } & \multirow{2}{*}{0.038} & Wall $2=10.101$ & 0.710 \\
\hline & & & & & Wall $3=14.097$ & 0.710 \\
\hline \multirow{2}{*}{3} & \multirow{2}{*}{ Window } & \multirow{2}{*}{2} & \multirow{2}{*}{ Glass } & \multirow{2}{*}{0.006} & Glass $1=0.8034$ & 0.960 \\
\hline & & & & & Glass $2=1.981$ & 0.960 \\
\hline 4 & Roof & 1 & Concrete & 0.010 & 12.735 & 1.000 \\
\hline
\end{tabular}

TABLE 2: Physical and thermal properties of different constituents materials of room 2.

\begin{tabular}{|c|c|c|c|c|c|c|}
\hline \multicolumn{7}{|c|}{ Room 2} \\
\hline \multirow{2}{*}{ S. number } & \multirow{2}{*}{ Component of the room } & \multirow{2}{*}{ Quantity } & \multirow{2}{*}{ Material } & \multicolumn{3}{|c|}{ Physical and thermal properties } \\
\hline & & & & Thickness (m) & Surface area $\left(\mathrm{m}^{2}\right)$ & Thermal conductivity $(\mathrm{W} / \mathrm{m}-\mathrm{K})$ \\
\hline 1 & Door & 1 & Wood & 0.035 & 2.12 & 0.150 \\
\hline \multirow{6}{*}{2} & \multirow{6}{*}{ Wall } & \multirow{6}{*}{6} & Brick & 0.228 & Wall $4=11.655$ & 0.710 \\
\hline & & & \multirow{5}{*}{ Plaster } & \multirow{5}{*}{0.038} & Wall $=2.812$ & 0.710 \\
\hline & & & & & Wall $6=2.146$ & 0.710 \\
\hline & & & & & Wall $7=15.651$ & 0.710 \\
\hline & & & & & Wall $8=13.394$ & 0.710 \\
\hline & & & & & Wall $9=6.512$ & 0.710 \\
\hline \multirow{2}{*}{3} & \multirow{2}{*}{ Window } & \multirow{2}{*}{2} & \multirow{2}{*}{ Glass } & \multirow{2}{*}{0.006} & Glass $1=5.922$ & 0.960 \\
\hline & & & & & Glass $2=0.803$ & 0.960 \\
\hline \multirow{2}{*}{4} & \multirow{2}{*}{ Roof } & \multirow{2}{*}{2} & \multirow{2}{*}{ Concrete } & \multirow{2}{*}{0.010} & $\mathrm{R} 1=8.140$ & 1.000 \\
\hline & & & & & $\mathrm{R} 2=14.461$ & 1.000 \\
\hline
\end{tabular}

fact that concrete material used in the construction process of a building has a good heat absorbing capacity and heat absorbed by roof helps in raising the temperature of the building envelope subsequently increasing the usage of airconditioning and refrigeration equipment. This increased usage of such equipment directly relies on the conventional energy for its operation, but with the application of the cool roof technology the heat gain through the roof into the building can be reduced. This reduction in heat gain also reduces the internal temperature of the building which in turn can reduce electricity consumption and reduce $\mathrm{CO}_{2}$ emissions into the environment. The consumption of the electricity gets reduced in a way because lesser work needs to be done by the cooling equipment in maintaining the temperature in the comfort level. The experimental studies were carried out for the selected site during the months of March, April, and May 2014. The various parameters were calculated (using relation as listed in the Appendix and values as listed in Tables 1 and 2) which include the variation of heat transfer through the roofs with different cool roof coatings for the different months as shown in Figures 3-8. Besides, percentage heat gain for the different months has also been calculated and presented (Figures 9-12).

Figures 3 and 4 show the variation of heat transfer and ambient temperature for room 1 and room 2, respectively, with time during the month of March. From Figure 3, it

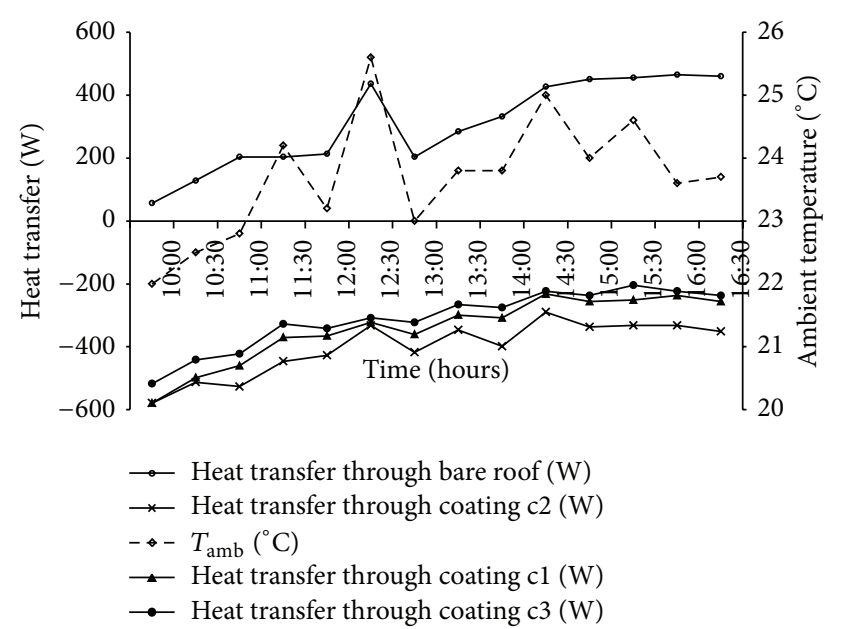

FIGURE 3: Variation of heat transfer from room 1 with different coatings and ambient temperature with time of the day during the month of March.

becomes evident that heat transfer through the bare roof, heat transfer through coating $\mathrm{cl}$, heat transfer through coating $\mathrm{c} 2$, and heat transfer through coating $\mathrm{c} 3$ show an increasing trend up to 14:00 hours and then show a decreasing trend. 
TABle 3: Specific technical details of different cool roof coatings.

\begin{tabular}{|c|c|c|}
\hline S. number & Name of the coating & $\begin{array}{l}\text { Technical details as per British Standard European Norm (BS EN) } \\
\text { and American Standard for Testing and Materials (ASTM) }\end{array}$ \\
\hline 1 & $\begin{array}{l}\text { Apex Ultima Acrylic } \\
\text { Emulsion (Asian Paints) "cl" }\end{array}$ & $\begin{array}{l}\text { Volume solid: } 60 \pm 2 \% \\
\text { Specific gravity: } 1.70 \pm 0.05 \\
\text { Theoretical spreading: } 2.4-1.2 \mathrm{~m}^{2} / \mathrm{L} \\
\text { Recommended dry film thickness: } 250-500 \text { microns/coat } \\
\text { Recommended wet film thickness: } 415-830 \text { microns/coat }\end{array}$ \\
\hline 2 & $\begin{array}{l}\text { Shaktiman Exterior Acrylic } \\
\text { Emulsion "c2" }\end{array}$ & $\begin{array}{l}\text { Supply viscosity: } 8-11 \text { poise @ } 30^{\circ} \mathrm{C} \\
\text { Coverage: } 90-110 \mathrm{ft}^{2} / \mathrm{L} \text { per coat }\end{array}$ \\
\hline 3 & Dr. Fixit Head Shield “c3” & $\begin{array}{l}\text { Tensile strength }(L / T): 42 / 48 \mathrm{~N} / \mathrm{mm}^{2} \\
\text { Tear resistance }(L / T): 340 / 310 \mathrm{~N} \\
\text { Hydrostatic pressure: }>50 \mathrm{~m}(5 \mathrm{bar}) \\
\text { Moisture vapour transmission: } 0.06\left(\mathrm{G} / \mathrm{m}^{2} / 24 \text { hours }\right) \\
\text { Chemical resistance: } \mathrm{pH} 2.0-11.5 \\
\text { Thermal conductivity: } 0.029 \mathrm{~W} / \mathrm{mK} \\
\text { Total solar energy rejected: } 94 \% \\
\text { Total heat gain: } 30 \mathrm{Btu} / \mathrm{hr} / \mathrm{ft}^{2}\end{array}$ \\
\hline
\end{tabular}

TABLE 4: Details of monitoring equipment [25].

\begin{tabular}{ll}
\hline Model name & Description \\
\hline Fluke 572-2 & High-temperature infrared \\
thermometer includes & (i) K-type thermocouple bead probe \\
& (ii) Durable hard case \\
& (iii) USB 2.0 computer interface cable \\
\hline Infrared temperature range & $-30^{\circ} \mathrm{C}$ to $900^{\circ} \mathrm{C}\left(-22^{\circ} \mathrm{F}\right.$ to $\left.1652^{\circ} \mathrm{F}\right)$ \\
\hline Infrared accuracy & $<-10^{\circ} \mathrm{C}: \pm 3^{\circ} \mathrm{C}$ \\
\hline
\end{tabular}

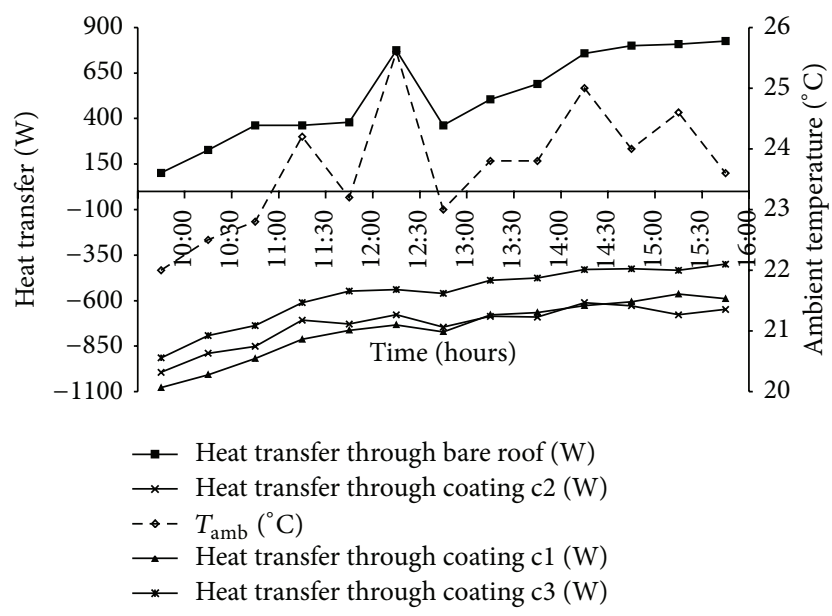

Figure 4: Variation of heat transfer from room 2 with different coatings and ambient temperature with time of the day during the month of March.

The maximum heat transfer is shown by bare roof at 12:30 hours when ambient temperature is $25.6^{\circ} \mathrm{C}$ which increases the temperature of room 1 and is happening due to the change in the ambient temperature while the effect of the ambient temperature on the coated roof is not extensive as compared to bare roof because cool roof coatings help in reducing the

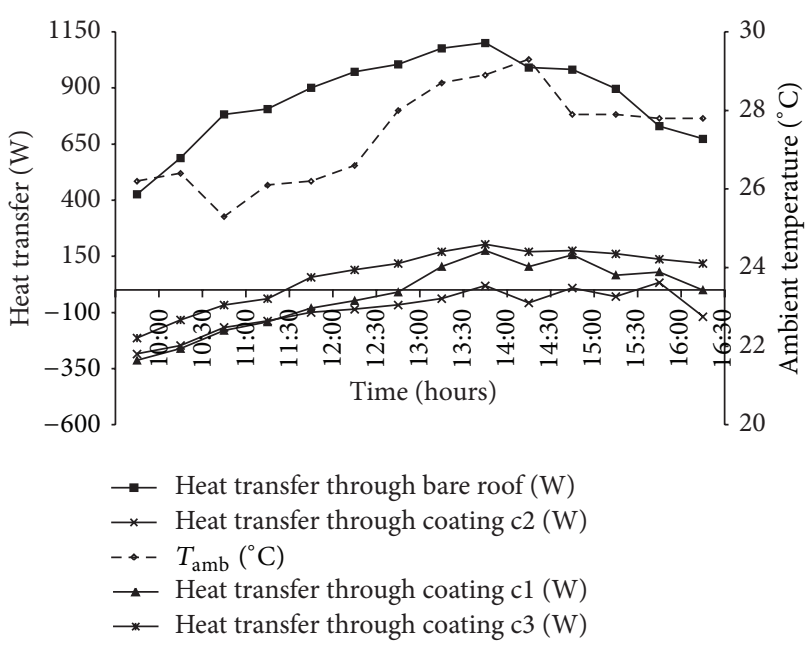

FIGURE 5: Variation of heat transfer from room 1 with different coatings and ambient temperature with time of the day during the month of April.

heat transfer rate, thereby maintaining the temperature of the building envelope. The percentage heat gain reduction by the different coatings for room 1 at 12:30 hours when ambient temperature is $25.6^{\circ} \mathrm{C}$ is about $26 \%$ for $\mathrm{cl}, 23 \%$ for $\mathrm{c} 2$, and $29 \%$ for $\mathrm{c} 3$. Coating $\mathrm{c} 3$ seems to be the worst whereas coating $\mathrm{c} 2$ is the best when analyzed for room 1 . However, the same trend of increasing heat transfer is also shown in Figure 4 for room 2 with the maximum heat transfer in bare roof at 12:30 hours when ambient temperature is $25.6^{\circ} \mathrm{C}$, but coating $\mathrm{c} 2$ in this case seems to be the most efficient. The percentage heat gain reduction by the different coatings for room 2 at 12:30 hours when ambient temperature is $25.6^{\circ} \mathrm{C}$ is $5 \%$ for $\mathrm{c} 1,12.4 \%$ for $\mathrm{c} 2$, and $30.43 \%$ for $\mathrm{c} 3$. This is happening because the heat storage capacity of coating c2 during the month of March decreases. The effect of ambient temperature on the heat transfer rate also shows a fluctuating trend. The negative sign in case of the heat transfer indicates that outside temperature during 
TABLE 5: Specifications of the external contact probe.

\begin{tabular}{ll}
\hline \multicolumn{2}{l}{ Contact measurements } \\
\hline K-type thermocouple input temperature range & $-270^{\circ} \mathrm{C}$ to $1372^{\circ} \mathrm{C}\left(-454^{\circ} \mathrm{F}\right.$ to $\left.2501^{\circ} \mathrm{F}\right)$ \\
\hline K-type thermocouple input accuracy & $<-40^{\circ} \mathrm{C}: \pm\left(1^{\circ} \mathrm{C}+0.2^{\circ} / 1^{\circ} \mathrm{C}\right)$ \\
(with ambient temperature $\left.23^{\circ} \mathrm{C} \pm 2^{\circ} \mathrm{C}\right)$ & $\geq-40^{\circ} \mathrm{C}: \pm 1 \%$ or $1^{\circ} \mathrm{C}$, whichever is greater \\
& $<-40^{\circ} \mathrm{F}: \pm\left(2^{\circ} \mathrm{F}+0.2^{\circ} / 1^{\circ} \mathrm{F}\right)$ \\
\hline K-type thermocouple & $\geq-40^{\circ} \mathrm{F}: \pm 1 \%$ or $2^{\circ} \mathrm{F}$, whichever is greater \\
\hline K-type thermocouple repeatability & $0.1^{\circ} \mathrm{C} / 0.1^{\circ} \mathrm{F}$ \\
\hline
\end{tabular}

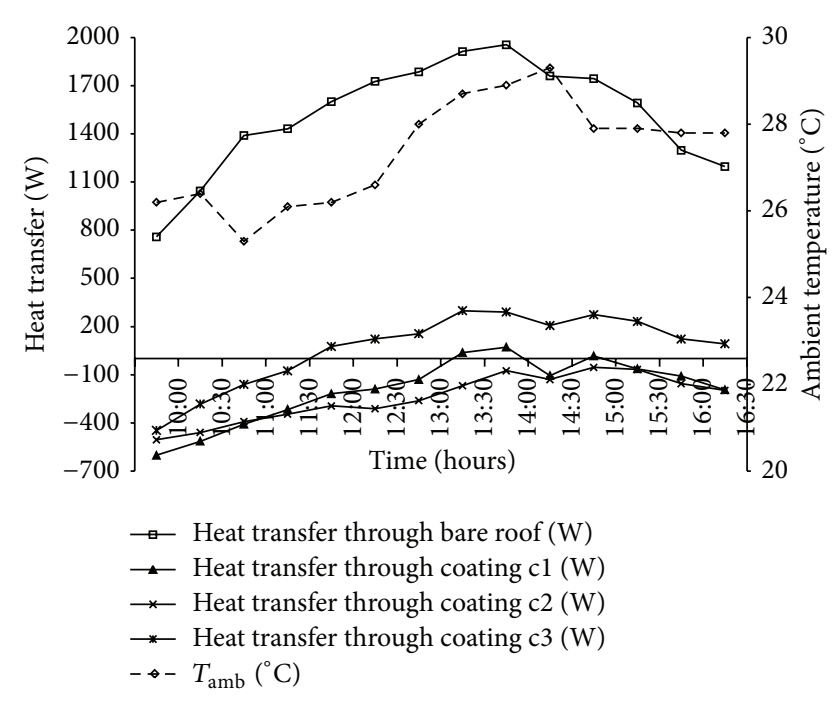

FIGURE 6: Variation of heat transfer from room 2 with different coatings and ambient temperature with time of the day during the month of April.

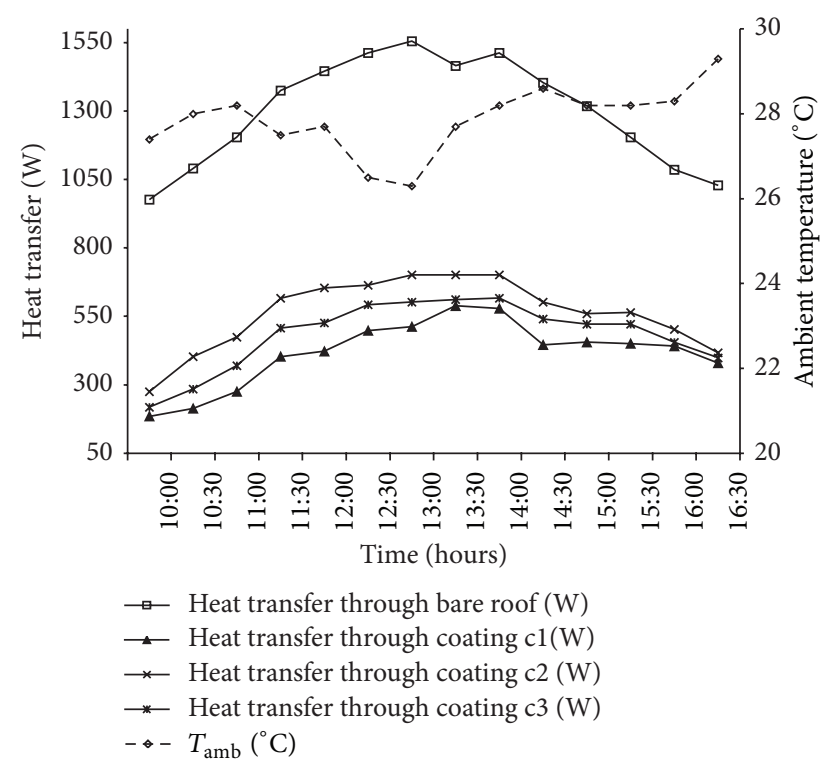

FIGURE 7: Variation of heat transfer from room 1 with different coatings and ambient temperature with time of the day during the month of May.

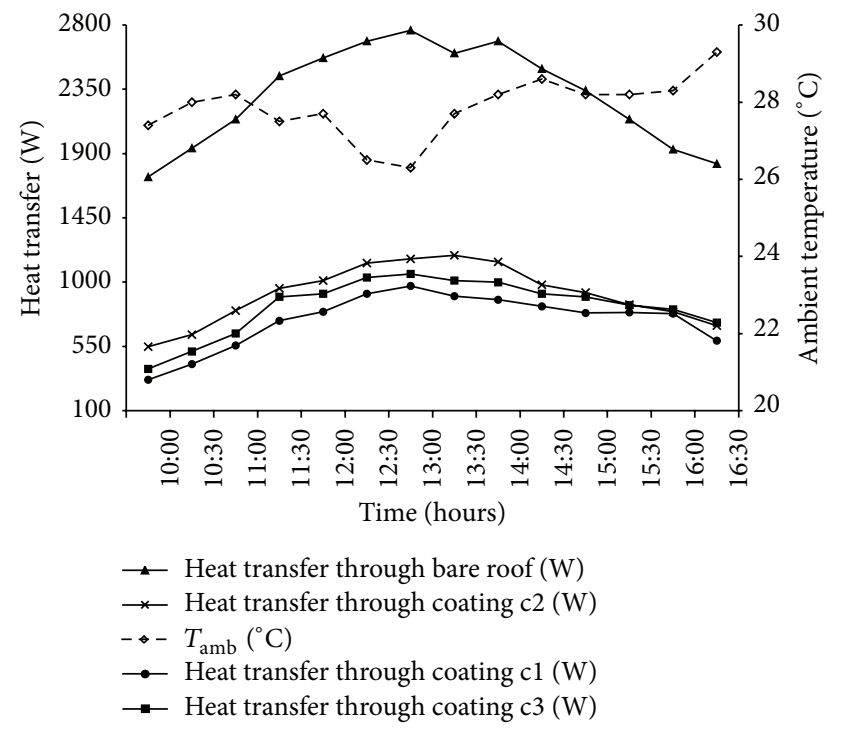

FIGURE 8: Variation of heat transfer from room 2 with different coatings and ambient temperature with time of the day during the month of May.

the month of March is less as compared to the temperature of the room which is to be kept fixed at $25^{\circ} \mathrm{C}$.

Figures 5 and 6 show the variation of heat transfer and ambient temperature for room 1 and room 2, respectively, with time during the month of April. From both figures, it becomes evident that heat transfer through the bare roof, heat transfer through coating $\mathrm{cl}$, heat transfer through coating $\mathrm{c} 2$, and heat transfer through coating $\mathrm{c} 3$ show an increasing trend up to 14:00 hours and then show a decreasing trend. The maximum heat transfer is shown by bare roof at 14:00 hours when ambient temperature is $28.9^{\circ} \mathrm{C}$, thereby increasing the temperature of room 1 , and is happening due to the change in the ambient temperature while the effect of the ambient temperature on the coated roof is not extensive as compared to bare roof because cool roof coatings help in reducing the heat transfer rate which maintains the temperature of the building envelope. The percentage heat gain reduction by the different coatings for room 1 at 14:00 hours when ambient temperature is $28.9^{\circ} \mathrm{C}$ is about $93 \%$ for $\mathrm{cl}, 98 \%$ for $\mathrm{c} 2$, and $81 \%$ for $\mathrm{c} 3$. However, the percentage heat gain reduction by the different coatings for room 2 at 14:00 hours when ambient temperature is $28.9^{\circ} \mathrm{C}$ is about $96.3 \%$ for $\mathrm{c} 1,96.12 \%$ for $\mathrm{c} 2$, and 


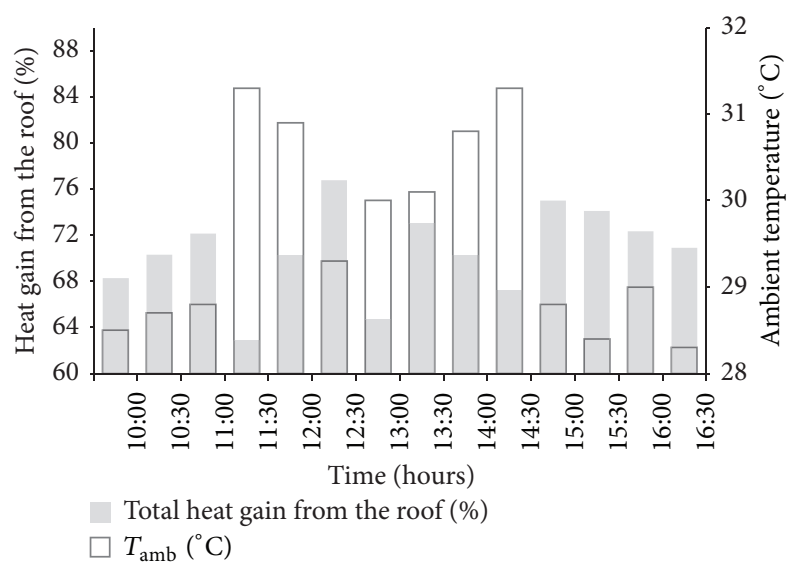

FIGURE 9: Variation of percentage heat gain from roof 1 and ambient temperature with time of the day during the month of April.

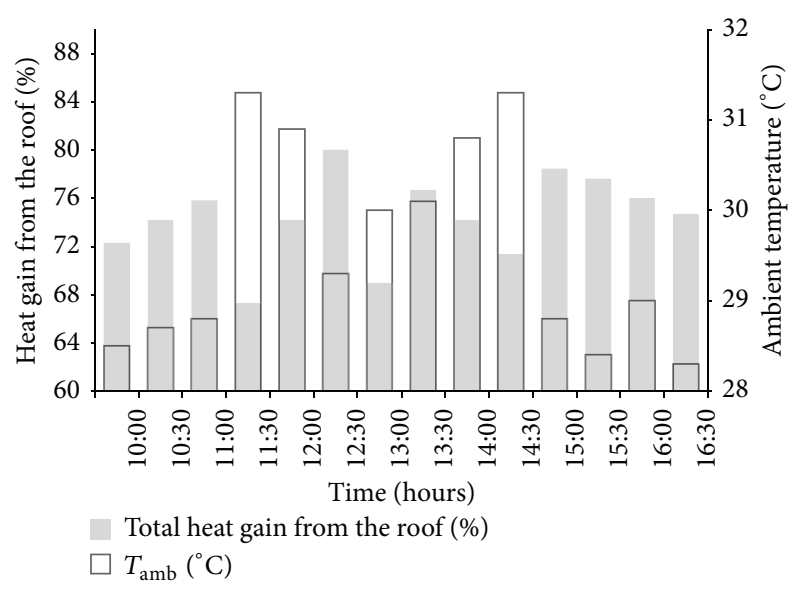

FIGURE 10: Variation of percentage heat gain from roof 2 and ambient temperature with time of the day during the month of April.

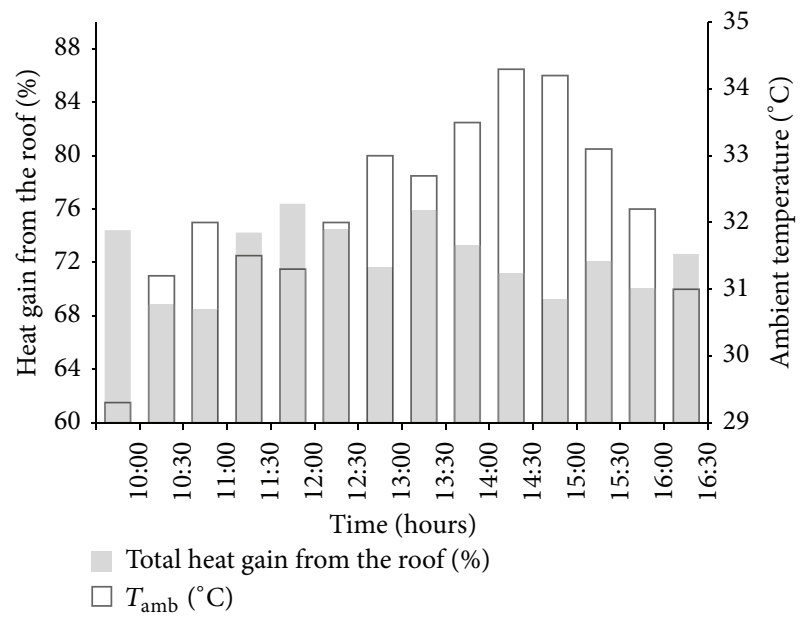

FIGURE 11: Variation of percentage heat gain from roof 1 and ambient temperature with time of the day during the month of May.

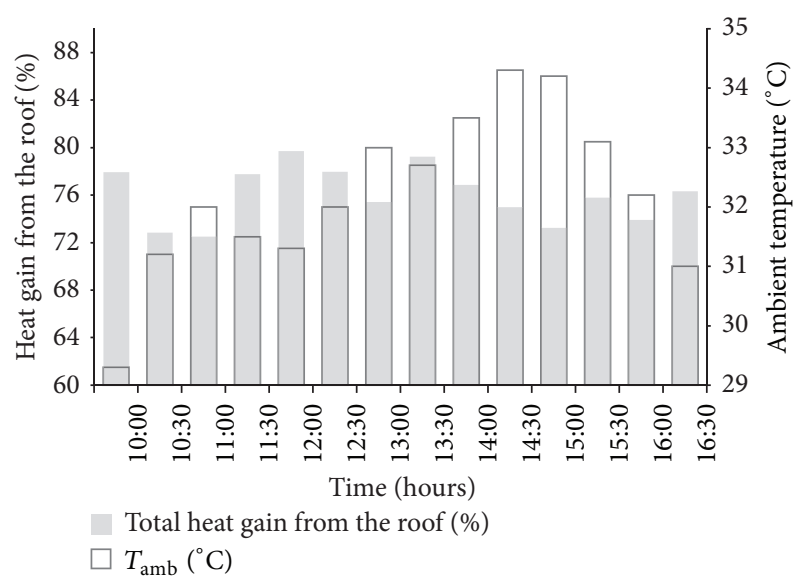

FIGURE 12: Variation of percentage heat gain from roof 2 and ambient temperature with time of the day during the month of May.

$85 \%$ for c3. Coating c2 seems to be an efficient coating while coating $\mathrm{c} 3$ seems to be the worst in terms of heat transfer for both rooms during the month of April. The effect of ambient temperature on the heat transfer rate also shows a fluctuating trend. The negative sign in case of the heat transfer indicates that outside temperature during the month of March is less as compared to the temperature of the room which is to be kept fixed at $25^{\circ} \mathrm{C}$.

Figures 7 and 8 show the variation of heat transfer and ambient temperature for room 1 and room 2, respectively, with time during the month of May. From both figures, it becomes evident that heat transfer through the bare roof, heat transfer through coating $\mathrm{cl}$, heat transfer through coating $\mathrm{c} 2$, and heat transfer through coating $\mathrm{c} 3$ show an increasing trend up to 13:00 hours and then show a decreasing trend. The maximum heat transfer is shown by bare roof at 13:00 hours when ambient temperature is $26.3^{\circ} \mathrm{C}$, thereby increasing the temperature of room 1 , and is happening due to the change in the ambient temperature while the effect of the ambient temperature on the coated roof is not extensive as compared to bare roof because cool roof coatings help in reducing the heat transfer rate, thereby maintaining the temperature of the building envelope. The percentage heat gain reduction by the different coatings for room 1 at 13:00 hours when ambient temperature is $26.3^{\circ} \mathrm{C}$ is about $67 \%$ for $\mathrm{cl}, 54.87 \%$ for $\mathrm{c} 2$, and $61.28 \%$ for $\mathrm{c} 3$. However, the percentage heat gain reduction by the different coatings for room 2 at 13:00 hours when ambient temperature is $26.3^{\circ} \mathrm{C}$ is about $64.78 \%$ for $\mathrm{cl}, 57.92 \%$ for $\mathrm{c} 2$, and $61.73 \%$ for $\mathrm{c} 3$. Coating $\mathrm{cl}$ seems to be an efficient coating while coating $\mathrm{c} 2$ seems to be the worst in terms of heat transfer for both rooms during the month of May. The effect of ambient temperature on the heat transfer rate is also showing a fluctuating trend.

Figures 9 and 10 show the variations of percentage heat gain from roof and ambient temperature with time during the month of April for room 1 and room 2, respectively. From the figures, it has been concluded that percentage heat gain in both cases fluctuates with the variation in the ambient temperature. The maximum percentage heat gain is about 
$76 \%$ and $80 \%$ for room 1 and room 2 , respectively, at 12:30 hours having ambient temperature of $29.3^{\circ} \mathrm{C}$.

Again, Figures 11 and 12 show the variations of percentage heat gain from roof and ambient temperature with time during the month of May for room 1 and room 2, respectively. From the figures, it has been concluded that percentage heat gain in both cases fluctuates with the change in the ambient temperature. The maximum percentage heat gain is about $77 \%$ and $80 \%$ for room 1 and room 2, respectively, at 12:00 noon having ambient temperature of $31.3^{\circ} \mathrm{C}$.

\section{Conclusions}

Two adjacent sites were selected for the analysis of cool roof pavements. The environmental impact and the energy aspects of each design were fully assessed through the experiments after applying cool roof pavements. The following important results were obtained from the experimental analysis.

(i) The percentage heat gain reduction by the different coatings for room 1 and room 2 during the month of March and at time of the maximum heat transfer (12:30 hours) when ambient temperature is $25.6^{\circ} \mathrm{C}$ revealed that coating $\mathrm{c} 2$ seems to be an efficient coating for room 1 while coating $\mathrm{cl}$ seems to be the best for room 2 during the month of March. This is happening because the heat storage capacity of coating $\mathrm{c} 2$ during the month of March decreases.

(ii) The percentage heat gain reduction by the different coatings for room 1 and room 2 during the month of April and at the time of the maximum heat transfer (14:00 hours) when ambient temperature is $28.9^{\circ} \mathrm{C}$ revealed that coating $\mathrm{c} 2$ seems to be an efficient coating while coating c3 seems to be the worst in terms of heat transfer for both rooms.

(iii) The percentage heat gain reduction by the different coatings for room 1 and room 2 during the month of May and at time of the maximum heat transfer (13:00 hours) when ambient temperature is $26.3^{\circ} \mathrm{C}$ revealed that coating $\mathrm{cl}$ seems to be an efficient coating while coating $\mathrm{c} 2$ seems to be the worst in terms of heat transfer for both rooms.

(iv) The maximum percentage heat gain is about $76 \%$ and $80 \%$ for room 1 and room 2 , respectively, during the month of April at an ambient temperature of $29.3^{\circ} \mathrm{C}$, whereas the maximum percentage heat gain is about $77 \%$ and $80 \%$ for room 1 and room 2, respectively, during the month of May at an ambient temperature of $31.3^{\circ} \mathrm{C}$.

(v) The cool roof technology evolves as a better green and clean technology in the building sector due to the fact that it helps in maintaining the temperature of building envelope at the comfort level, thereby reducing the consumption of electricity for cooling equipment.

\section{Appendix}

\section{Numerical Calculation of Heat Transfer in Building}

The numerical calculation of heat transfer in building is calculated using the simple mathematical relation of heat transfer which is given as

$$
Q=U \times A \times \Delta T,
$$

where " $Q$ " is the heat transfer rate in watts, " $U$ " is the overall heat transfer coefficient $\left(3.72 \mathrm{~W} / \mathrm{m}^{2}-\mathrm{K}\right)$, " $A$ " is the total roof area $\left(35.34 \mathrm{~m}^{2}\right)$, and " $\Delta T$ " is the temperature difference.

Also, "cl" is the name of the coating (Apex Ultima Acrylic Emulsion) (Asian Paints).

"c2" and "c3" are the names of Shaktiman Exterior Acrylic Emulsion and Dr. Fixit Head Shield, respectively.

\section{Conflict of Interests}

The authors declare that there is no conflict of interests regarding the publication of this paper.

\section{References}

[1] G. Sarlos and A. Dauriat, "Energy: a challenge for humanity in the 21st century," in Proceedings of the International Conference on Energy and the Environment, pp. 1-5, Shanghai, China, December 2003.

[2] F. Kuznik and J. Virgone, "Experimental assessment of a phase change material for wall building use," Applied Energy, vol. 86, no. 10, pp. 2038-2046, 2009.

[3] "Energy Efficiency Improvement in Commercial Building (2010-2012)," United Nations Development Program India, Global Environmental Facility Project Document.

[4] M. Santamouris, Ed., Energy and Climate in the Urban Built Environment, James and James Science Publishers, London, UK, 2001.

[5] R. Potter, Extreme Weather, Climate and Preparedness in the American Mind, 2012.

[6] A. Gray, Cool Roof Pays off in Energy Saving and Environmental Benefits, Building Operating Management, 2005.

[7] Guidelines for Selecting Cool Roof, US Department of Energy, 2010.

[8] A. Synnefa, M. Santamouris, and K. Apostolakis, "On the development, optical properties and thermal performance of cool colored coatings for the urban environment," Solar Energy, vol. 81, no. 4, pp. 488-497, 2007.

[9] M. Santamouris, "Heat Island research in Europe: the state of the art," Advances in Building Energy Research, vol. 1, no. 1, pp. 123-150, 2007.

[10] http://www.greaterkashmir.com/news/2010/May/29/energyconsumption-in-jammu-up-by-12-pc-62.asp.

[11] “"Cool roofs" mandatory for all new buildings," http://archive .indianexpress.com/news/-cool-roofs-mandatory-for-all-newbuildings/988898.

[12] H. Akbari, R. Levinson, and L. Rainer, "Monitoring the energyuse effects of cool roofs on California commercial buildings," Energy and Buildings, vol. 37, no. 10, pp. 1007-1016, 2005. 
[13] S. Boixo, M. Diaz-Vicente, A. Colmenar, and M. A. Castro, "Potential energy savings from cool roofs in Spain and Andalusia," Energy, vol. 38, no. 1, pp. 425-438, 2012.

[14] H. Akbari, S. Konopacki, and M. Pomerantz, "Cooling energy savings potential of reflective roofs for residential and commercial buildings in the United States," Energy, vol. 24, no. 5, pp. 391-407, 1999.

[15] http://usa.sarnafil.sika.com/en/group/literature/what-new/docool-roofs-fit-in-cool-climates.html.

[16] R. Levinson, H. Akbari, and J. C. Reilly, "Cooler tile-roofed buildings with near-infrared-reflective non-white coatings," Building and Environment, vol. 42, no. 7, pp. 2591-2605, 2007.

[17] A. Synnefa, M. Santamouris, and H. Akbari, "Estimating the effect of using cool coatings on energy loads and thermal comfort in residential buildings in various climatic conditions," Energy and Buildings, vol. 39, no. 11, pp. 1167-1174, 2007.

[18] H. Suehrcke, E. L. Peterson, and N. Selby, "Effect of roof solar reflectance on the building heat gain in a hot climate," Energy and Buildings, vol. 40, no. 12, pp. 2224-2235, 2008.

[19] K. L. Uemoto, N. M. N. Sato, and V. M. John, "Estimating thermal performance of cool colored paints," Energy and Buildings, vol. 42, no. 1, pp. 17-22, 2010.

[20] C. Romeo and M. Zinzi, "Impact of a cool roof application on the energy and comfort performance in an existing nonresidential building. A Sicilian case study," Energy and Buildings, vol. 67, pp. 647-657, 2013.

[21] H. Akbari and H. D. Matthews, "Global cooling updates: Reflective roofs and pavements," Energy and Buildings, vol. 55, pp. 2-6, 2012.

[22] T. Xu, J. Sathaye, H. Akbari, V. Garg, and S. Tetali, "Quantifying the direct benefits of cool roofs in an urban setting: reduced cooling energy use and lowered greenhouse gas emissions," Building and Environment, vol. 48, no. 1, pp. 1-6, 2012.

[23] G. M. Revel, M. Martarelli, M. Á. Bengochea et al., "Nano based coatings with improved NIR reflecting properties for building envelope materials: development and natural aging effect measurement," Cement and Concrete Composites, vol. 36, no. 1, pp. 128-135, 2013.

[24] H. Torío, A. Angelotti, and D. Schmidt, "Exergy analysis of renewable energy-based climatisation systems for buildings: a critical view," Energy and Buildings, vol. 41, no. 3, pp. 248-271, 2009.

[25] http://www.fluke.com/fluke/inen/thermometers/infraredthermometers/Fluke-572-2-Infrared\%20thermom-eter.htm? $\mathrm{PID}=76844$. 

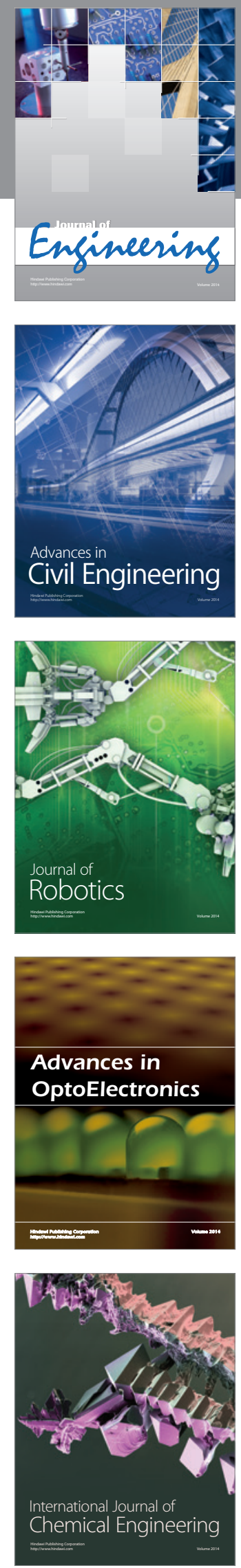

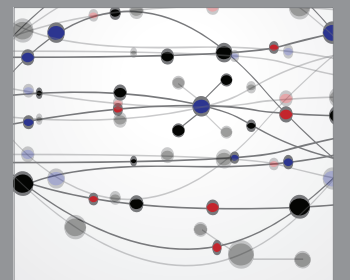

The Scientific World Journal
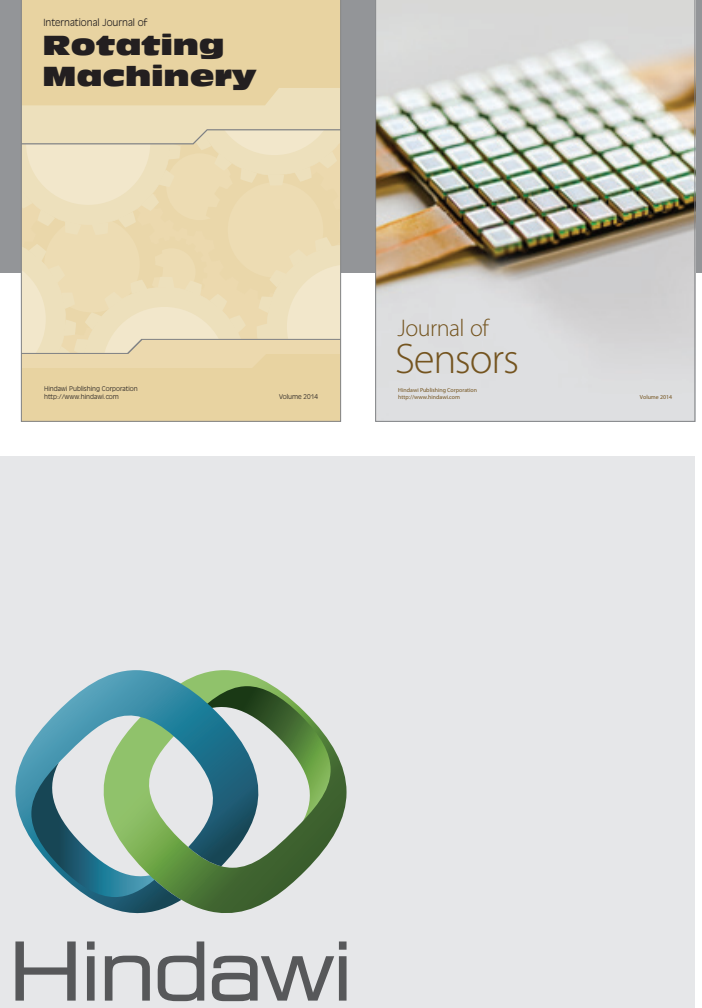

Submit your manuscripts at http://www.hindawi.com
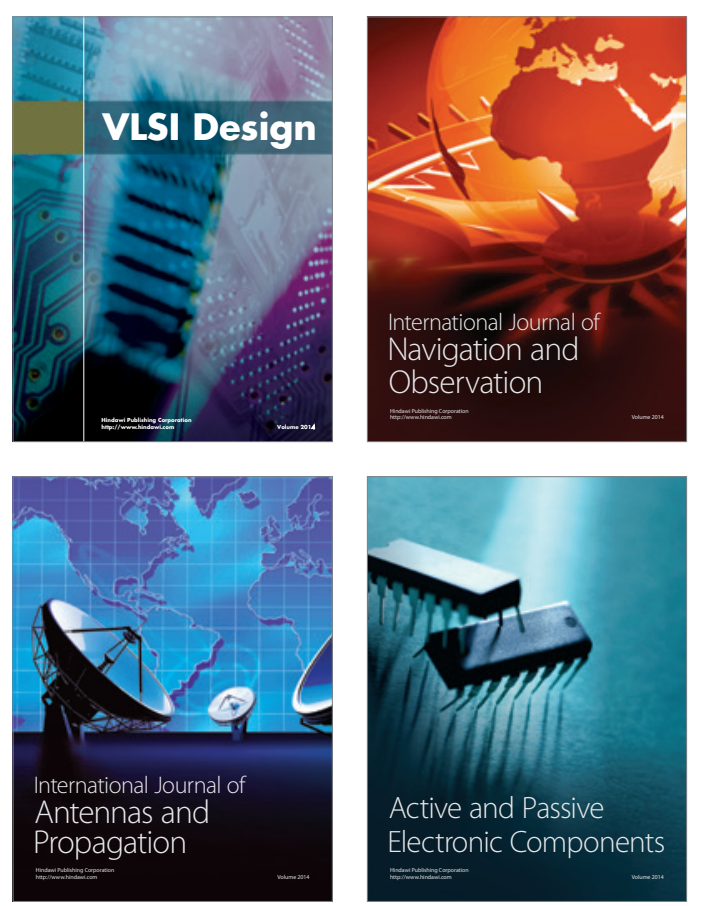
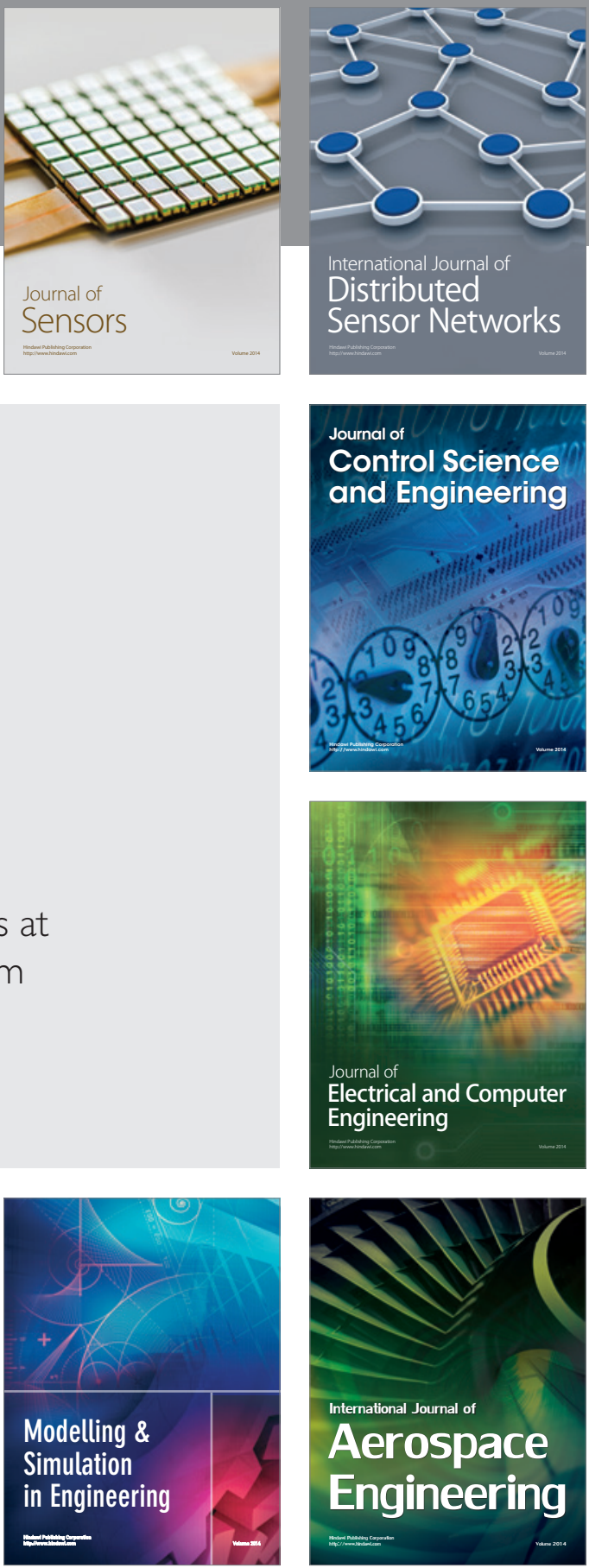

Journal of

Control Science

and Engineering
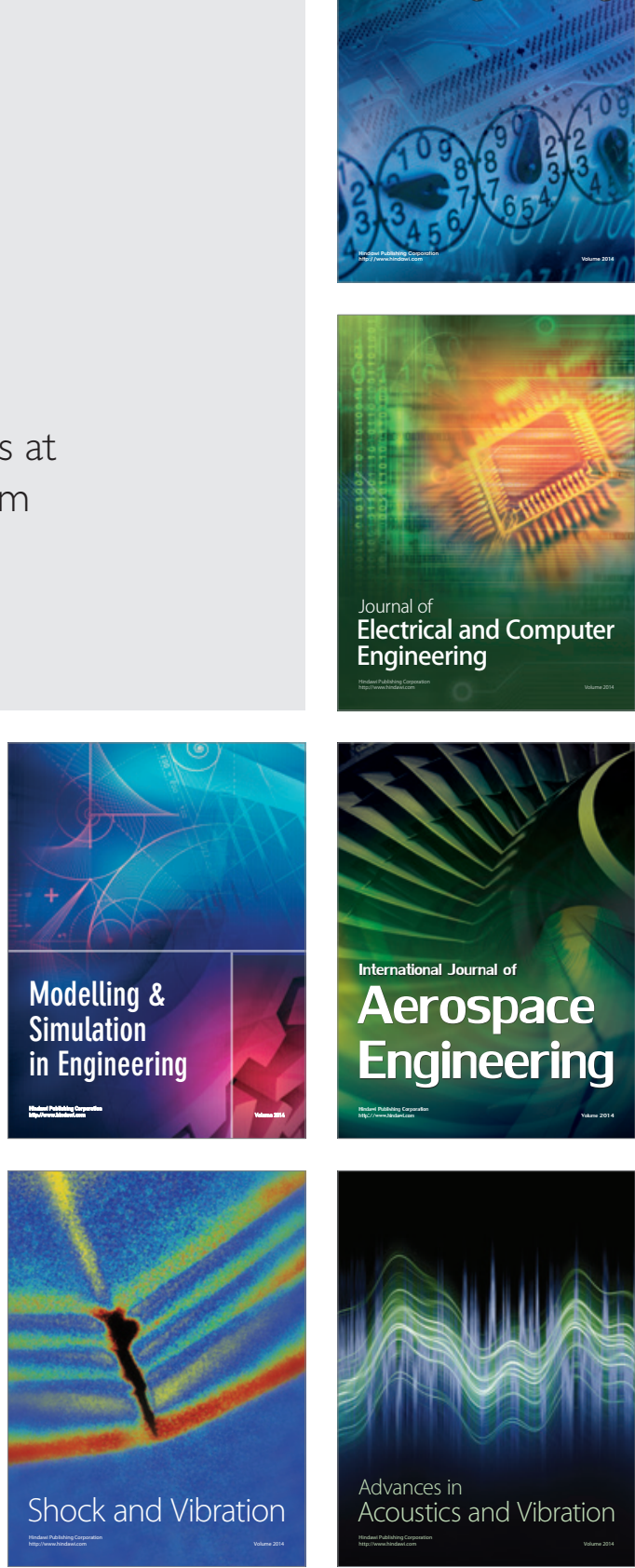